\title{
Mechanical and chemical weeding effects on the weed structure in durum wheat
}

\author{
Andrzej Woźniak \\ Department of Herbology and Plant Cultivation Techniques, University of Life Sciences in Lublin, Poland
}

\begin{abstract}
A three-year field experiment was performed to study weed infestation of durum wheat at the stage of emergence and full maturity. Two weeding systems (WS) were used in the post-harvest period: i) mechanical weeding (MW); and ii) chemical weeding $(\mathrm{CW})$. In the MW system, soil underwent shallow ploughing at a depth of 10-12 cm and double harrowing (after ploughing and 3 weeks later), whereas glyphosate only was used in the CW system. In the springtime, in both MW and CW systems, a tillage set consisting in a cultivator, a string roller and harrowing was used. Overall, the number of weeds $\mathrm{m}^{2}$, the number of weed species and the value of weed diversity indices were always higher in MW than in the CW systems in each study year at both the emergence and full maturity stage of durum wheat. The study demonstrated that at the stage of durum wheat emergence, more weeds per $\mathrm{m}^{2}$ occurred in the MW than in the CW system in each study year. Moreover, the MW systems was characterized by a higher number of weed species as well as by a higher value of weed diversity index compared to the $\mathrm{CW}$ system.
\end{abstract}

\section{Introduction}

Glyphosate herbicides are the most commonly used plant protection agents in crop stands (Dill, 2005; Heap and Duke, 2018).

Correspondence: Andrzej Woźniak, Department of Herbology and Plant Cultivation Techniques, University of Life Sciences in Lublin, Poland. E-mail: andrzej.wozniak@up.lublin.pl

Key words: Species composition; Shannon-Wiener's diversity index; Jaccard's similarity index; degrees of phytosociological constancy.

Acknowledgements: Research supported by Poland's Ministry of Science and Higher Education as part of the statutory activities of the Department of Herbology and Plant Cultivation Techniques, University of Life Sciences in Lublin.

Received for publication: 24 October 2019.

Revision received: 28 March 2020.

Accepted for publication: 28 March 2020.

(C) Copyright: the Author(s), 2020

Licensee PAGEPress, Italy

Italian Journal of Agronomy 2020; 15:1559

doi:10.4081/ija.2020.1559

This article is distributed under the terms of the Creative Commons Attribution Noncommercial License (by-nc 4.0) which permits any noncommercial use, distribution, and reproduction in any medium, provided the original author(s) and source are credited.
They are used to eradicate weeds on stubble fields and barren lands, and in stands of genetically modified organism (GMO) plants resistant to glyphosate (Duke, 2005; Young et al., 2013; Koning et al., 2019). Glyphosate-resistant crops are grown primarily in the USA, Argentina, Brazil, and China (Nandula et al., 2005; Reddy and Koger, 2005). In the European Union, where no such crops are cultivated, this herbicide is used on stubble fields, usually in the direct sowing and strip-till systems (SantínMontanyá et al., 2016; Koning et al., 2019). Weed control with herbicides, particularly with the non-selective glyphosate, is highly effective and efficient (Haliniarz et al., 2018; Woźniak and Rachon, 2019), but unfortunately contributes to the development of herbicide-resistant weed biotypes (Van Gessel, 2001; Yuan et. al., 2002; Perez et al., 2004; Koger and Reddy, 2005; Owen and Zelaya, 2005; Collavo and Sattin, 2014). This is due to the use of reduced doses of herbicides (compared to the recommended ones) that may selectively affect little-sensitive weeds and induce their resistance to plant protection agents (Koning et al., 2019). As reported by Heap and Duke (2018), thirty-eight weed species have now evolved resistance to glyphosate, distributed across 37 countries and in 34 different crops and six non-crop situations.

Weed infestation of crops is a resultant of the co-occurrence of multiple factors, such as the: weed seed bank in the soil (Swanton et al., 2000; Vanasse and Leroux, 2000; Woźniak, 2007; Restuccia et al. 2019), tillage systems (Chauhan et al., 2012; Gawęda et al., 2018; Woźniak and Soroka, 2018), plant succession in crop rotation (Moyer et al., 1994; Woźniak and Soroka, 2015), and weeding systems (Rasmussen et al., 2006; Peigné et al., 2007; Pardo et al., 2008). Cultivation tools destroy annual weeds mechanically, but at the same time increase the number of vegetative species which reproduce through rhizomes, runners, bulbs or roots. During ploughing, seeds are being ploughed out onto soil surface, afterwards they sprout and emerge under convenient conditions. In turn, seeds which have just fallen on soil surface are in the ploughing process mixed into the deeper soil layers from where only a few of them are capable to emerge (Yenish et al., 1992; Riemens et al., 2007). As demonstrated in our previous study (Woźniak, 2007), in the conventional tillage system, the highest number of weed seeds may be found in the soil layer at $1-10 \mathrm{~cm}$, then a lower number in the soil layer at $10-25 \mathrm{~cm}$, whilst the lower number on soil surface $(0-1 \mathrm{~cm})$. In contrast, the no-till system increases weed seed bank in the topsoil (Tørresen and Skuterud, 2002; Mohler et al., 2006). In turn, an experiment performed by Bàrberi et al. (2001) has demonstrated that up to $90 \%$ of the seed bank may be present on soil surface and that, when emerged, these seedlings may be destroyed by chemical or mechanical treatments.

The use of various solutions in soil tillage affects the extent of weed infestation and weed biodiversity (Peigné et al., 2007; Woźniak and Rachon, 2019). Glyphosate herbicides used in the direct sowing system reduce the number of weed species compared to the conventional and reduced tillage, as well as contribute to the vertical distribution of weeds in the crop stand (Woźniak and Soroka, 2017; Woźniak, 2018). 
This study aimed to evaluate the effect of weeding systems the extent of weed infestation and weed biodiversity at the stage of emergence and full maturity of durum wheat.

\section{Materials and methods}

\section{Habitat localization and climatic conditions}

A field experiment was performed in the years 2016-2018 at the Uhrusk Experimental Station of the University of Life Sciences in Lublin (south-eastern Poland; 51 $\left.{ }^{\circ} 18^{\prime} 12^{\prime \prime} \mathrm{N}, 23^{\circ} 36^{\prime} 48^{\prime \prime} \mathrm{E}\right)$. It was set up in a randomized sub-block design in 3 replicates having the size of $6 \times 25 \mathrm{~m}$. The soil under experiment contained $24.1 \%$ of the silty fraction and $13.2 \%$ of the dust fraction and was classified as Rendzic Phaeozem (IUSS Working Group WRB 2015). It was characterized by alkaline $\mathrm{pH}\left(\mathrm{pH}_{\mathrm{KCL}}=7.3\right)$, high contents of available phosphorus (140 $\mathrm{mg} \mathrm{P} \mathrm{kg}^{-1}$ ) and potassium $\left(300 \mathrm{mg} \mathrm{K} \mathrm{kg}^{-1}\right)$, and by a moderate content of magnesium (61 mg $\mathrm{Mg} \mathrm{kg}^{-1}$ ). Organic carbon content in the soil accounted for $8.20 \mathrm{~g} \mathrm{~kg}^{-1}$ and that of total nitrogen - for $0.90 \mathrm{~g} \mathrm{~N} \mathrm{~kg}^{-1}$. In the period 1990-2015, the average annual sum of atmospheric precipitation at the study area reached $607 \mathrm{~mm}$, but from durum wheat sowing (April) until harvest (August) the rainfalls accounted for $339 \mathrm{~mm}$. In the study period (2016-2018), the sums of monthly precipitations from April to August were highly diversified - the lowest ones occurred in $2018(220 \mathrm{~mm})$, higher in $2017(297 \mathrm{~mm})$, and the highest in 2016 (374 mm). Considering air temperature, the warmest turned out to be the year $2018\left(18.2^{\circ} \mathrm{C}\right.$ on average), colder was $2016\left(16.2^{\circ} \mathrm{C}\right)$, and the coldest appeared to be $2017\left(15.9^{\circ} \mathrm{C}\right)$.

\section{Crop management}

Two weeding systems (WS) were used in the post-harvest period: i) mechanical weeding (MW); and ii) chemical weeding (CW). In the MW system, soil underwent shallow ploughing at a depth of 10-12 $\mathrm{cm}$ and double harrowing (immediately after ploughing and 3 weeks later), whereas glyphosate $\left(360 \mathrm{~g} \mathrm{~L}^{-1}, 4 \mathrm{~L} \mathrm{ha}^{-1}\right)$ only was used in the CW system. In both weeding systems, pea (Pisum sativum L.) was used as the previous crop to spring durum wheat (Triticum durum Desf., Duromax cultivar). In the MW system, pre-winter ploughing at a depth of 20-25 cm was performed at the beginning of November. In the springtime, in both MW and CW systems a tillage set was used which consisted of a cultivator, a string roller, and a harrow. Nitrogen, phosphorus, and potassium were administered at doses of: $\mathrm{N}-120 \mathrm{~kg}$ $\mathrm{ha}^{-1}, \mathrm{P}-35 \mathrm{~kg} \mathrm{ha}^{-1}$, and $\mathrm{K}-80 \mathrm{~kg} \mathrm{ha}^{-1}$. Fertilization was calculated according soil chemical analysis. The phosphorus-based and potassium-based fertilizers were used once before durum wheat sowing, whereas the nitrogen-based ones were applied in the three following terms: i) before sowing - $50 \mathrm{~kg} \mathrm{ha}^{-1}$; ii) at the tillering stage (22-23 $\mathrm{BBCH})-40 \mathrm{~kg} \mathrm{ha}^{-1}$; and ;) at the flag leaf emergence stage (39 $\mathrm{BBCH})$ - $30 \mathrm{~kg} \mathrm{ha}^{-1}$ (BBCH Working Group 2001). In all study years, durum wheat was sown in the first decade of April at the sowing density of 450 seeds per $\mathrm{m}^{2}$.

\section{Performance traits and statistical analysis}

The number and species composition of weeds were evaluated in two terms: i) at the emergence stage (12-13 $\mathrm{BBCH})$; and ii) at the full maturity stage $(89 \mathrm{BBCH})$ of durum wheat. The number of weeds and their species composition were determined on the area of $\mathrm{m}^{2}$ of each plot using the frame twice having the size of $1 \times 0.5$ $\mathrm{m}$. At the $89 \mathrm{BBCH}$ stage, analyses were also conducted to determine the air-dry weight of weeds. Weeds picked at this stage from the designated areas were placed in a ventilated room until dry matter has been obtained. Then, the following biodiversity indices and degrees were determined: Shannon-Wiener's diversity index $\left(H^{\prime}\right)$, Jaccard's similarity index $(K j)$, and degrees of phytosociological consistency (Woźniak and Soroka, 2015; Woźniak, 2018).

Values of the Shannon-Wiener's index $\left(H^{\prime}\right)$ were computed from the following formula:

$H^{\prime}=-\mathrm{S}\left(\frac{n i}{N}\right) \log \left(\frac{n i}{N}\right)$, where: $n i-$ number of individuals of species, and $N$ - total number of individuals of all species.

Values of the Jaccard's similarity index were computed using the following formula:

$K j=\frac{c}{a+b-c}, \quad$ where $a-$ number of species in sample a; $b$-number of species in sample $b ; c$-number of common species in both samples.

The frequency of weeds occurrence was evaluated using five classes: V (80-100\%), IV (60-80\%), III (40-60\%), II (20-40\%), and I $(<20 \%)$.

Results were elaborated statistically with the analysis of variance (ANOVA) method, whereas the significance of differences between the compared mean values (years $\mathrm{x}$ weeding systems) was estimated with the Tukey's $H S D$ test, $\mathrm{P}<0.05$.

\section{Results}

\section{Weed infestation of durum wheat at the stage of emer- gence (12-13 BBCH)}

The number of weeds per $\mathrm{m}^{2}$ at durum wheat emergence stage was found to depend on both: weeding systems (WS), study year (Y), and their interaction WS x Y (Tables 1 and 2). In each study

Table 1. Number of weeds per $\mathrm{m}^{2}$ at the emergence stage of durum wheat (12-13 $\mathrm{BBCH})$.

\begin{tabular}{lccc} 
Years (Y) & $\begin{array}{c}\text { Weeding systems (WS) } \\
\text { Mechanical weeding } \\
\text { (MW) }\end{array}$ & $\begin{array}{c}\text { Mean } \\
\text { Chemical weeding } \\
\text { (CW) }\end{array}$ \\
2016 & 20.1 & 2.5 & 11.3 \\
2017 & 35.3 & 3.4 & 19.4 \\
\hline 2018 & 34.5 & 11.6 & 23.1 \\
Mean & 29.9 & 5.8 & - \\
\hline \multicolumn{4}{c}{$H_{0.05}$ for WS $=5.1 ; \mathrm{Y}=6.3 ; \mathrm{WS} \mathrm{x} \mathrm{Y=9.7}$} \\
\hline
\end{tabular}

Table 2. Number of weed species at the emergence stage of durum wheat (12-13 BBCH).

\begin{tabular}{|c|c|c|c|}
\hline Years (Y) & $\begin{array}{l}\text { Weeding syst } \\
\text { Mechanical weeding } \\
\text { (MW) }\end{array}$ & $\begin{array}{l}\text { ms (WS) } \\
\text { Chemical weeding } \\
\text { (CW) }\end{array}$ & Mean \\
\hline 2016 & 14.0 & 6.0 & 10.0 \\
\hline 2017 & 17.0 & 5.0 & 11.0 \\
\hline 2018 & 14.0 & 6.0 & 10.0 \\
\hline Mean & 15.0 & 5.7 & - \\
\hline
\end{tabular}

ns, not significant. 
year, a significantly higher number of weeds was recorded on plots cultivated in the MW system than CW system. The higher weed number per $\mathrm{m}^{2}$ was also determined in the years 2017 and 2018 compared to 2016. The MW plots were also characterized by a higher number of weed species than the CW plots. The weeding systems and study years affected also the species composition of weeds. In 2016, the prevailing species on MW plots included: Stellaria media, Galium aparine, Consolida regalis, and Polygonum persicaria; whereas these on CW plots included: $S$. media, Viola arvensis, Capsella bursa-pastoris, and Apera spicaventi (Figure 1). In 2017, S. media, Papaver rhoeas, and G. aparine prevailed on MW plots; whereas S. media, Sonchus asper, and $V$. arvensis on CW plots (Figure 2). In 2018, the most abundant species on MW plots were: $S$. media, $P$. rhoeas, and G. aparine; and on CW plots: S. media, S. asper, and V. arvensis (Figure 3).

The weeding systems and study years affected also values of Shannon-Wiener's diversity index $\left(H^{\prime}\right)$ and Jaccard's similarity index $(K j)$ (Table 3). Significantly greater species diversity of weeds $\left(H^{\prime}\right)$ was observed on MW than on CW plots. Differences were also observed among study years, with greater diversity reported in 2017 and 2018 than in 2016 . In contrast, higher values of the similarity index $(K j)$ were determined for the weed community from the CW system than for the community from the MW system as wells as in the year 2016 compared to 2017 and 2018.

The variance component analysis demonstrated that the number of weeds per $\mathrm{m}^{2}$ depended to a greater extent on the weeding system (WS) than on study year (Y) and their co-effect (WS x Y); and that the number of weed species was affected to a greater extent by WS x Y co-effect and WS. In addition, it showed that the values of the Shannon-Wiener's diversity index $\left(H^{\prime}\right)$ were equally influenced by WS, WS x Y and Y; whereas these of the Jaccard's similarity index $(K j)$ were affected more by the WS x Y co-effect and similarly influenced by WS and Y (Table 4).

\section{Weed infestation of durum wheat at the stage of full maturity (89 BBCH)}

At the full maturity stage of durum wheat, in each study year, a significantly higher number of weeds per $\mathrm{m}^{2}$ (by 74.3-79.5\%) was found on plots cultivated in the MW than in the CW system (Table 5). Also the air-dry weight of weeds was higher in the MW

Table 3. Values of Shannon-Wiener's diversity index $\left(H^{\prime}\right)$ and Jaccard's similarity index $\left(K_{j}\right)$ at the emergence stage of durum wheat (12-13 BBCH).

\begin{tabular}{|c|c|c|c|}
\hline Years (Y) & $\begin{array}{l}\text { Weeding sys } \\
\text { Mechanical weeding } \\
\text { (MW) } \\
\text { Shannon-Wiene }\end{array}$ & $\begin{array}{l}\text { Ms (WS) } \\
\text { Chemical weeding } \\
\text { (CW) } \\
\text { diversity index }\end{array}$ & Mean \\
\hline 2016 & 1.03 & 0.53 & 0.78 \\
\hline 2017 & 1.17 & 0.60 & 0.88 \\
\hline 2018 & 1.03 & 0.74 & 0.89 \\
\hline Mean & 1.07 & 0.62 & - \\
\hline & $H S D_{0.05}$ for $W S=0.07 ;$ & $=0.09 ; \mathrm{WS} \times \mathrm{Y}=0.12$ & \\
\hline & Jaccard's inde & of similarity & \\
\hline 2016 & 0.23 & 0.49 & 0.36 \\
\hline 2017 & 0.18 & 0.36 & 0.27 \\
\hline 2018 & 0.24 & 0.31 & 0.28 \\
\hline Mean & 0.22 & 0.39 & - \\
\hline
\end{tabular}

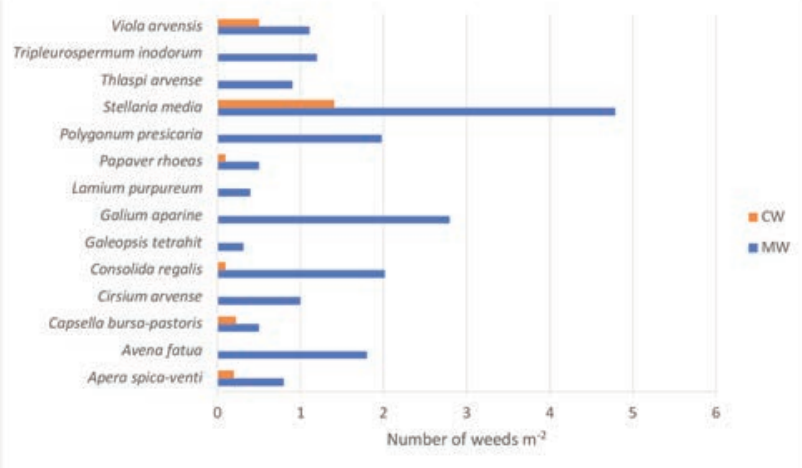

Figure 1. Species composition of weeds at the emergence stage of durum wheat $(12-13 \mathrm{BBCH})$ in 2016, $\mathrm{CW}$ - Chemical weeding; MW - Mechanical weeding.

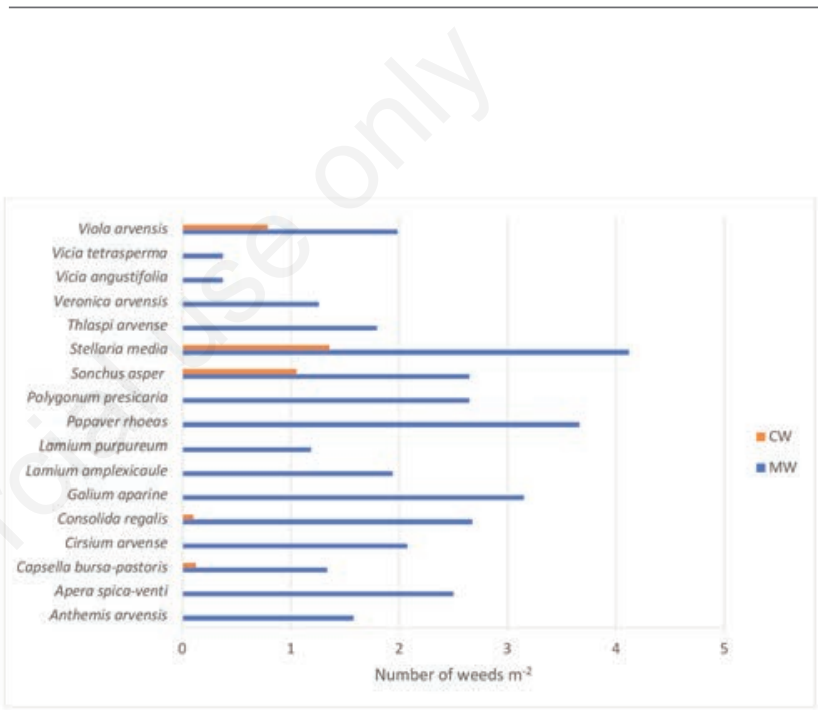

Figure 2. Species composition of weeds at the emergence stage of durum wheat (12-13 BBCH) in 2017, CW - Chemical weeding; MW - Mechanical weeding.

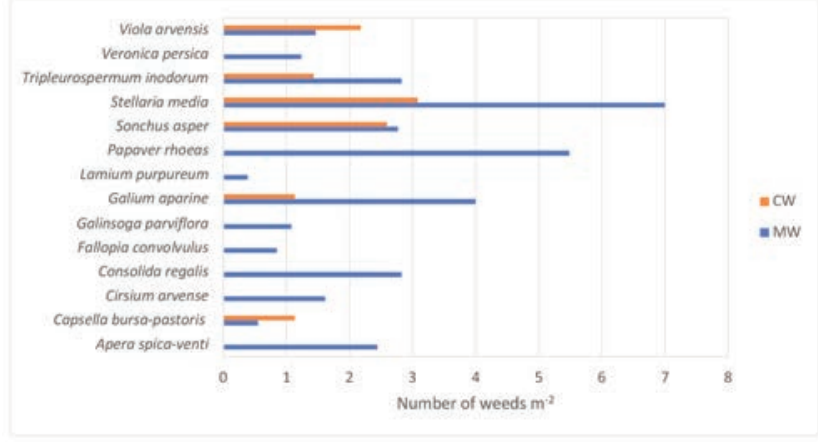

Figure 3. Species composition of weeds at the emergence stage of durum wheat (12-13 BBCH) in 2018, CW - Chemical weeding; MW - Mechanical weeding. 
than in the CW system (by 52.1-65.1\%). The MW plots were also characterized by a higher number of weed species (from 10 to 16 species) compared to the CW plots (Table 6). The number of weed species on MW and CW plots was found to depend on study year, with a higher species number identified in 2018 than in 2016. In 2016, the prevailing species on MW plots included: P. rhoeas, Avena fatua, S. media, and A. spica-venti; whereas these prevailing on CW plots included: Vicia angustifolia, V. arvensis, and Fumaria officinalis (Figure 4). In 2017, A. fatua, P. rhoeas, S. media, and G. aparine prevailed on MW plots; whereas A. spica-venti, A. fatua,

Table 4. Variance analysis of indicators of weed infestation of durum wheat stand at the emergence stage (12-13 $\mathrm{BBCH})$.

\begin{tabular}{lcccc} 
& Value & WS & Y & WS X Y \\
Specification & $F$ & 198.5 & 92.3 & 134.6 \\
Number of weeds $\mathrm{m}^{-2}$ & $P$ & $* *$ & $*$ & $*$ \\
Number of species & $F$ & 12.9 & 2.3 & 14.9 \\
& $P$ & $*$ & ns & $*$ \\
\hline Shannon-Wiener diversity index $\left(H^{\prime}\right)$ & $F$ & 63.0 & 12.3 & 29.6 \\
& $P$ & $*$ & $*$ & $*$ \\
Jaccard's similarity index $\left(K_{j}\right)$ & $F$ & 12.1 & 13.3 & 21.9 \\
& $P$ & $*$ & $*$ & $*$ \\
\hline
\end{tabular}

WS, Weeding systems; $\mathrm{Y}$, Years, ${ }^{*} \mathrm{P}<0.05 ; * * \mathrm{P}<0.05$; ns, not significant.

Table 5. Number and air-dry weight of weeds per $\mathrm{m}^{2}$ at the full maturity stage of durum wheat $(89 \mathrm{BBCH})$.

\begin{tabular}{|c|c|c|c|}
\hline Years (Y) & $\begin{array}{l}\text { Weeding syst } \\
\text { Mechanical weeding } \\
\text { (MW) } \\
\text { Number of }\end{array}$ & $\begin{array}{l}\text { Chemical weeding } \\
\text { (CW) } \\
\text { veeds } \mathrm{m}^{-2}\end{array}$ & Mean \\
\hline 22016 & 82.5 & 16.9 & 49.7 \\
\hline 2017 & 71.6 & 17.4 & 44.5 \\
\hline 2018 & 81.6 & 21.0 & 51.3 \\
\hline Mean & 78.6 & 18.4 & - \\
\hline & $H S D_{0.05}$ for $\mathrm{WS}=9.3$ & $=n s ; \mathrm{WS} \times \mathrm{Y}=13.2$ & \\
\hline & Air-dry weight 0 & weeds in $\mathrm{g} \mathrm{m}^{-2}$ & \\
\hline 2016 & $a^{2}$ & 21.3 & 41.2 \\
\hline 2017 & 57.8 & 22.9 & 40.4 \\
\hline 2018 & 65.3 & 26.2 & 45.8 \\
\hline Mean & 61.4 & 23.5 & - \\
\hline & $H S D_{0.05}$ for $\mathrm{WS}=7.5$ & $=n s ; \mathrm{WS} \times \mathrm{Y}=12.1$ & \\
\hline
\end{tabular}

ns, not significant.

Table 6. Number of weed species at the full maturity stage of durum wheat $(89 \mathrm{BBCH})$.

\begin{tabular}{|c|c|c|c|}
\hline Years (Y) & $\begin{array}{l}\text { Weeding syste } \\
\text { Mechanical weeding } \\
\text { (MW) }\end{array}$ & $\begin{array}{l}\text { ns (WS) } \\
\text { Chemical weeding } \\
\text { (CW) }\end{array}$ & Mean \\
\hline 2016 & 18.0 & 8.0 & 13.0 \\
\hline 2017 & 23.0 & 11.0 & 17.0 \\
\hline 2018 & 28.0 & 12.0 & 20.0 \\
\hline Mean & 23.0 & 10.3 & - \\
\hline \multicolumn{4}{|c|}{$H S D_{0.05}$ for $\mathrm{WS}=4.1 ; \mathrm{Y}=6.0 ; \mathrm{WS} \times \mathrm{Y}=9.8$} \\
\hline
\end{tabular}

and S. media on CW plots (Figure 5). In 2018, the most abundant species on MW plots were: A. fatua, S. media, Chenopodium album, and $P$. rhoeas; whereas on $\mathrm{CW}$ plots: A. fatua, A. spicaventi, S. media, and P. aviculare (Figure 6).

The weeding systems and study years affected also values of the diversity and similarity indices (Table 7). A higher value of the Shannon-Wiener's diversity index $\left(H^{\prime}\right)$ was computed for the MW than for the CW system as well as in the year 2018 than in the year 2016. Opposite observations were made for the Jaccard's similarity index $(K j)$, the values of which were higher in the CW than in the MW system, and in 2016 than in 2018 .

The variance component analysis showed that the number of weeds per $\mathrm{m}^{2}$ depended to a greater extent on WS than on WS $\mathrm{x} Y$ co-effect (Table 8), and that the number of weed species was similarly affected by WS and Y, and less affected by their co-effect. Values of the Shannon-Wiener's diversity index $\left(H^{\prime}\right)$ were influ-

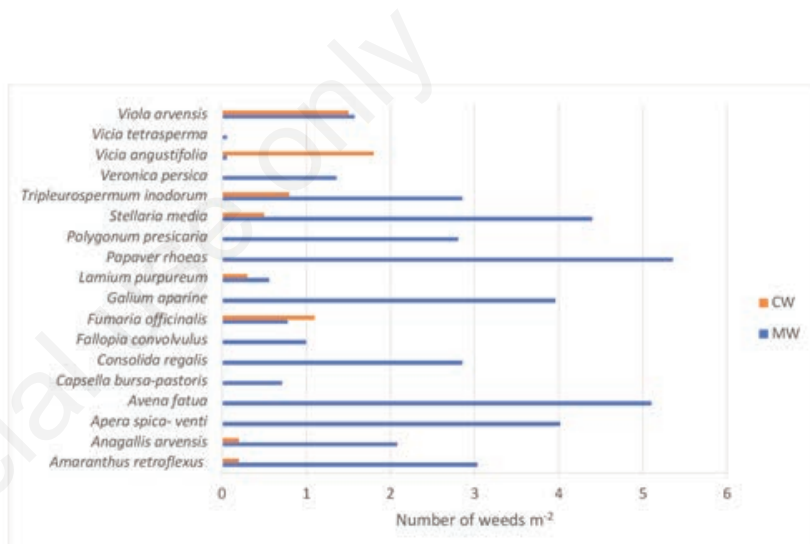

Figure 4. Species composition of weeds at the full maturity stage of durum wheat $(89 \mathrm{BBCH})$ in $2016, \mathrm{CW}$ - Chemical weeding; MW - Mechanical weeding.

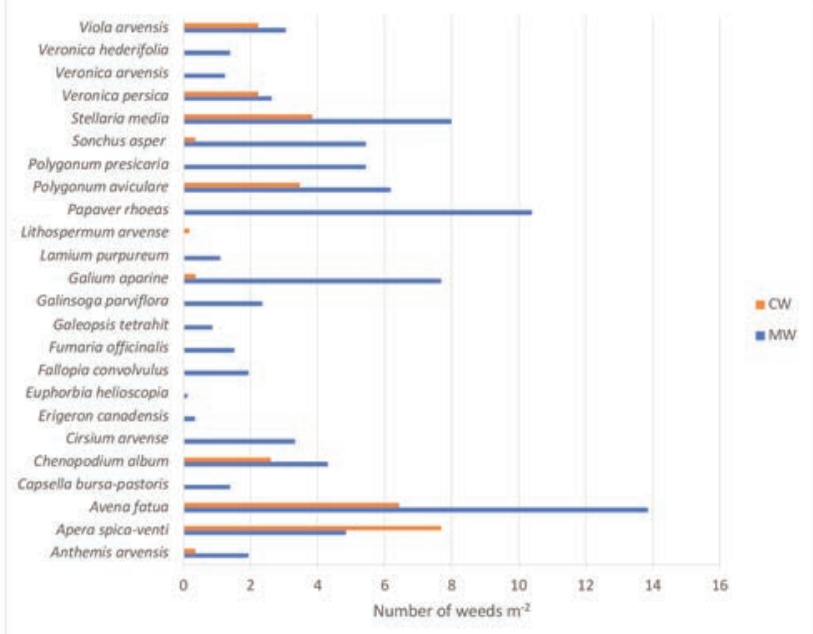

Figure 5. Species composition of weeds at the full maturity stage of durum wheat $(89 \mathrm{BBCH})$ in $2017, \mathrm{CW}$ - Chemical weeding; MW - Mechanical weeding. 
enced to a greater extent by WS and WS x Y co-effect, and to a lesser extent by $\mathrm{Y}$; whereas values of the Jaccard's similarity index $(K j)$ were similarly affected by WS and Y, and less affected by WS x Y co-effect. In the MW system, 29 species of dicotyledonous weeds and 3 species of monocotyledonous weeds were identified in durum wheat stand (Table 9). P. aviculare, $S$. asper, S. media, Tripleurospermum inodorum, Veronica persica, $V$. arvensis, and $A$. fatua occurred in the durum wheat crop in the highest V class of phytosociological consistency, whereas $C$. regalis, Lamium amplexicaule, L. purpureum, P. rhoeas, and Echinochloa crus-galli in the IV degree. The number of dicotyledonous and monocotyledonous weed species identified on CW plots accounted for 11 and 2, respectively. This highest $\mathrm{V}$ class of phytosociological constancy was ascribed to: P. aviculare, S. media, V. arvensis, and A. fatua, whereas the IV degree to: L. amplexicaule, $T$. inodorum and $V$. persica.

\section{Discussion}

Weeds are companion species to crops that strongly respond to agrotechnical treatments (Gunton et al., 2011; Pinke et al., 2012; Fried et al., 2012). As shown in our study and in investigations conducted by Hernández Plaza et al. (2015), Woźniak and Rachoń (2019), and Woźniak (2018), the conventional tillage system increases the species diversity of weed communities compared to the no-till system with the use of glyphosate. In our previous experiment Woźniak and Soroka (2017), on plots treated with glyphosate herbicide, the weed community was shown to include only short-term species, whereas on plots cultivated in the conventional and reduced systems it included both short-term and perennial species (Convolvulus arvensis, Cirsium arvense, Elymus repens and $S$. arvensis). According to Hernández Plaza et al. (2015), weeds produce more seeds (but with a lower mass) in the direct sowing system with glyphosate than in the conventional and

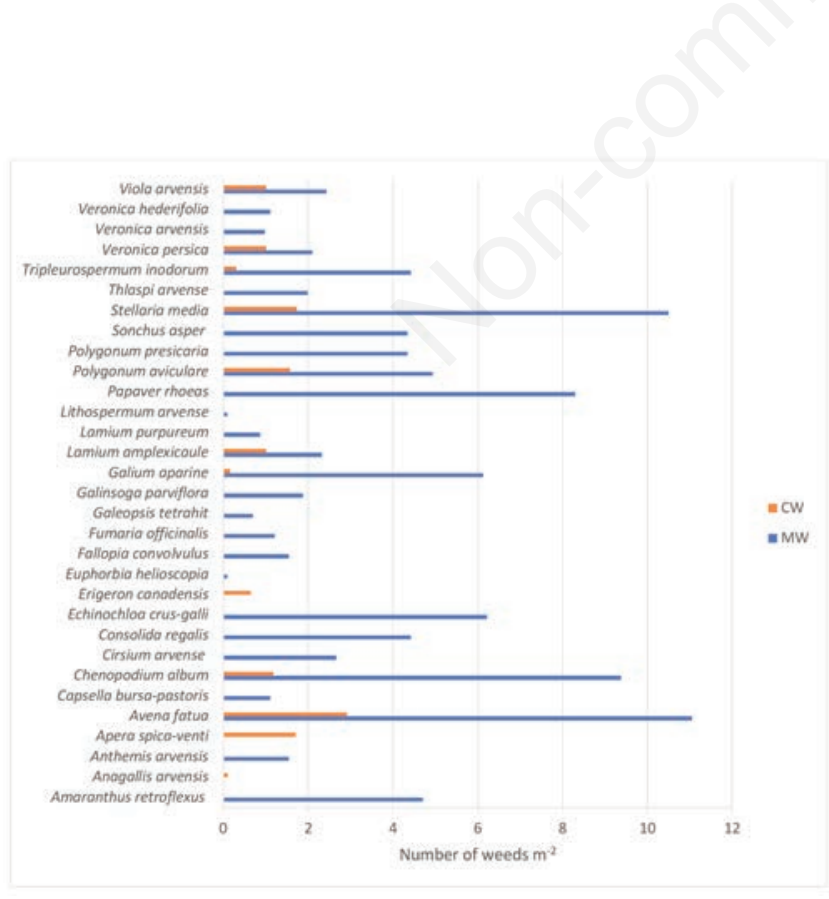

Figure 6. Species composition of weeds at the full maturity stage of durum wheat $(89 \mathrm{BBCH})$ in $2018, \mathrm{CW}$ - Chemical weeding; MW - Mechanical weeding. reduced systems. In turn, seeds from the conventional system were characterized by highly variable size and mass, which caused a greater diversity and, consequently, higher germination capability, growth dynamics of seedlings, competitiveness, and diversity of the weed community (Hernández Plaza et al., 2015). Our previous study (Woźniak and Soroka, 2017) demonstrated that tillage systems affected also the species composition and vertical distribution of weeds in cereal stands. A. spica-venti was found to prevail on the plots treated with glyphosate, whereas Avena fatua on plots cultivated in the conventional and reduced systems without the herbicide. Another research of ours (Woźniak and Rachoń, 2019) showed an increased contribution of the biomass of monocotyledonous weeds in the total weed biomass on plots treated with glyphosate compared to the plots cultivated with the conventional tillage system. In the presented experiment, the weeding systems and study years affected also values of the Shannon-Wiener' diversity index $\left(H^{\prime}\right)$ and Jaccard's similarity index $(K j)$. Greater diversity of the weed community was found in the MW system than in the CW system. Similar dependencies were reported by Van Gessel (2001), Koger and Reddy (2005), Hernández Plaza et al. (2015), Woźniak (2018), and Koning et al. (2019). Also the number of weed species was higher in the MW system (32 species) than in the CW system (13 species). In our previous study (Woźniak and Soroka, 2015), cereals were accompanied by communities of sege-

Table 7. Values of Shannon-Wiener's diversity index $\left(H^{\prime}\right)$ and Jaccard's similarity index $\left(K_{j}\right)$ at the full maturity stage of durum wheat $(89 \mathrm{BBCH})$.

\begin{tabular}{|c|c|c|c|}
\hline Years (Y) & $\begin{array}{l}\text { Weeding systen } \\
\text { Mechanical weeding } \\
\text { (MW) } \\
\text { Shannon-Wiener d }\end{array}$ & $\begin{array}{l}\text { ns (WS) } \\
\text { Chemical weeding } \\
\text { (CW) } \\
\text { liversity index }\end{array}$ & Mean \\
\hline 2016 & 1.13 & 0.79 & 0.96 \\
\hline 2017 & 1.21 & 0.86 & 1.03 \\
\hline 2018 & 1.30 & 0.97 & 1.13 \\
\hline Mean & 1.21 & 0.87 & - \\
\hline & $H S D_{0.05}$ for $W S=0.08 ; Y=$ & $=0.10 ; \mathrm{WS} \times Y=0.15$ & \\
\hline & Jaccard's index & of similarity & \\
\hline 2016 & 0.21 & 0.49 & 0.35 \\
\hline 2017 & 0.19 & 0.42 & 0.30 \\
\hline 2018 & 0.17 & 0.33 & 0.25 \\
\hline Mean & 0.19 & 0.41 & - \\
\hline & $H S D_{0.05}$ for $\mathrm{WS}=0.05 ; \mathrm{Y}=$ & $=0.07 ; W S \times Y=0.12$ & \\
\hline
\end{tabular}

Table 8. Variance analysis of indicators of weed infestation of durum wheat stand at the full maturity stage $(89 \mathrm{BBCH})$.

\begin{tabular}{lcccc} 
Specification & Value & WS & Y & WS x Y \\
Number of weeds $\mathrm{m}^{-2}$ & $\mathrm{~F}$ & 121.3 & 32.8 & 89.4 \\
& $\mathrm{P}$ & $* *$ & $\mathrm{~ns}$ & $*$ \\
Number of species & $\mathrm{F}$ & 24.2 & 29.6 & 16.3 \\
& $\mathrm{P}$ & $*$ & $*$ & $*$ \\
\hline Shannon-Wiener diversity index $\left(H^{\prime}\right)$ & $\mathrm{F}$ & 72.3 & 31.9 & 69.4 \\
& $\mathrm{P}$ & $* *$ & $*$ & $*$ \\
Jaccard's similarity index $\left(K_{j}\right)$ & $\mathrm{F}$ & 13.3 & 14.8 & 13,9 \\
& $\mathrm{P}$ & $*$ & $*$ & $*$ \\
\hline
\end{tabular}

WS,Weeding systems; $\mathrm{Y}$, Years, ${ }^{*} \mathrm{P}<0.05 ;{ }^{*} \mathrm{P}<0.05 ;$ ns, not significant. 
tal weeds, mainly representatives of the class Stellarietea mediae R.Tx, Lohm. et Prsg 1950. These communities were composed of one-year or two-year segetal species, and on fields with low agrotechnical ingenerence also of perennial ruderal and even meadow species. Their development is influenced by the type and properties of soil, water-air balance, crop species, plant succession in crop rotation, and intensity of agrotechnical measures. These findings were also confirmed in our field experiment.

Table 9. Degrees of phytosociological constancy of weed species at the full maturity stage of durum wheat $(89 \mathrm{BBCH})$.

\begin{tabular}{|c|c|c|}
\hline Species composition & $\begin{array}{l}\text { Mechanical } \\
\text { weeding } \\
\text { (MW) }\end{array}$ & $\begin{array}{c}\text { Chemical } \\
\text { weeding } \\
\text { (CW) }\end{array}$ \\
\hline \multicolumn{3}{|l|}{ Dicotyledonous species } \\
\hline Amaranthus retroflexus $\mathrm{L}$. & III & - \\
\hline Anagallis arvensis L. & II & - \\
\hline Anthemis arvensis $\mathrm{L}$. & III & - \\
\hline Capsella bursa-pastoris (L.) Medicus & III & II \\
\hline Chenopodium album (L.) & III & III \\
\hline Cirsium arvense (L.) Scopoli & I & - \\
\hline Consolida regalis Gray & IV & - \\
\hline Erigeron canadensis L. & - & I \\
\hline Euphorbia helioscopia L. & I & - \\
\hline Fallopia convolvulus (L.) Löve & II & - \\
\hline Fumaria officinalis L. & I & - \\
\hline Galeopsis tetrahit $\mathrm{L}$. & I & - \\
\hline Galinsoga parviflora Cav. & II & - \\
\hline Galium aparine $\mathrm{L}$. & V & V \\
\hline Lamium amplexicaule $\mathrm{L}$. & IV & IV \\
\hline Lamium purpureum $\mathrm{L}$. & IV & - \\
\hline Lithospermum arvense $\mathrm{L}$. & I & - \\
\hline Papaver rhoeas L. & IV & - \\
\hline Polygonum aviculare $\mathrm{L}$. & V & V \\
\hline Polygonum persicaria L. & I & - \\
\hline Sonchus asper (L.) Hill & V & III \\
\hline Stellaria media (L.) Villars & V & V \\
\hline Thlaspi arvense L. & III & - \\
\hline $\begin{array}{l}\text { Tripleurospermum inodorum (L.) } \\
\text { Schultz.Bip. }\end{array}$ & V & IV \\
\hline Veronica persica Poir. & V & IV \\
\hline Veronica arvensis L. & I & - \\
\hline Veronica hederifolia $\mathrm{L}$. & I & - \\
\hline Vicia angustifolia Reichard & I & - \\
\hline Vicia tetrasperma (L.) Schreb. & II & - \\
\hline Viola arvensis Murray & V & V \\
\hline Number of species & 29 & 11 \\
\hline \multicolumn{3}{|l|}{ Monocotyledonous species } \\
\hline Apera spica-venti $\mathrm{L}$. & I & II \\
\hline Avena fatua $\mathrm{L}$. & V & V \\
\hline Echinochloa crus-galli (L.) P.B. & IV & - \\
\hline Number of species & 3 & 2 \\
\hline
\end{tabular}

\section{Conclusions}

Chemical weeding $(\mathrm{CW})$ used after harvest of the previous crop (pea) caused a decrease the number and biomass of weeds in durum wheat compared to the mechanical weeding (MW). In addition, it contributed to the less diverse species composition and a lower number of weed species in durum wheat. On plots cultivated with both weeding systems, there prevailed short-term species, most of which were representants of the class of dicotyledonous weeds. In turn, a representative of monocotyledonous weeds Avena fatua - was found in each study year and in each weeding system. In the MW system, we identified also a perennial species - Cirsium arvense - occurring in the I degree of phytosociological constancy.

The choice of the weed control method should be adapted to the number and species composition of the weeds.

\section{References}

Bàrberi $\mathrm{P}$, Bonari E, Mazzoncini $\mathrm{M}$, García-Torres L, Benites $\mathrm{J}$, Martínez-Vilela A, 2001. Weed density and composition in winter wheat as influenced by tillage systems. Conservation agriculture, a worldwide challenge. pp 451-5 in Proceedings of the First World Congress on Conservation Agriculture, Madrid, Spain.

BBCH Working Group, 2001. Growth stages of mono-and dicotyledonous plants. 2. Edition, 2001. Edited by Uwe Meier. Federal Biological Research Centre for Agriculture and Forestry. Available from: https:/www.politicheagricole.it/flex/AppData/ WebLive/Agrometeo/MIEPFY800/BBCHengl2001.pdf

Chauhan BS, Singh RG, Mahajan G, 2012. Ecology and management of weeds under conservation agriculture: a review. Crop Prot. 38:57-65.

Collavo A, Sattin M, 2014. First glyphosate-resistant Lolium spp. biotypes found in a European annual arable cropping system also affected by ACCase and ALS resistance. Weed Res. 54:325-34.

Dill GM, 2005. Glyphosate-resistant crops: history, status and future. Pest Manag. Sci. 61:219-24.

Duke SO, 2005. Taking stock of herbicide-resistant crops ten years after introduction. Pest Manag. Sci. 61:211-8.

Fried G, Kazakou E, Gaba S, 2012. Trajectories of weed communities explained by traits associated with species' response to management practices. Agr. Ecosyst. Environ. 158:147-55.

Gawęda D, Woźniak A, Harasim E, 2018. Weed infestations of winter wheat depend on the forecrop and the tillage system. Acta Agrobot. 71:1744.

Gunton RM, Petit S, Gaba S, 2011. Functional traits relating arable weed communities to crop characteristics. J. Veg. Sci. 22:541-50.

Haliniarz M, Nowak A, Woźniak A, Sekutowski TR, Kwiatkowski CA, 2018. Production and economic effects of environmentally friendly spring wheat production technology. Pol. J. Environ. Stud. 27:1523-32.

Heap I, Duke SO, 2018. Overview of glyphosate-resistant weeds worldwide. Pest Manag. Sci. 74:1040-9.

Hernández Plaza E, Navarrete L, González-Andújar JL, 2015. Intensity of soil disturbance shapes response trait diversity of weed communities: The long-term effects of different tillage systems. Agr. Ecosyst. Environ. 207:101-8.

IUSS Working Group WRB, 2015. World Reference Base for Soil Resources 2014, update 2015. International soil classification system for naming soils and creating legends for soil maps. 
World Soil Resources Reports No. 106. Rome, FAO.

Koger CH, Reddy KN, 2005. Role of absorption and translocation in the mechanism of glyphosate resistance in horseweed (Conyza canadensis). Weed Sci. 53:84-9.

Koning LA, de Mol F, Gerowitt B, 2019. Effects of management by glyphosate or tillage on the weed vegetation in a field experiment. Soil Till. Res. 186:79-86.

Mohler CL, Frisch JC, McCulloch CE, 2006. Vertical movement of weed seed surrogates by tillage implements and natural processes. Soil Till. Res. 86:110-22.

Moyer JR, Roman ES, Lindwall CW, Blackshaw RE, 1994. Weed management in conservation tillage systems for wheat production in North and South America. Crop Prot. 13:243-59.

Owen MDK, Zelaya IA, 2005. Herbicide-resistant crops and weed resistance to herbicides. Pest Manag. Sci. 61:301-11.

Perez A, Alister C, Kogan M, 2004. Absorption, translocation and allocation of glyphosate in resistant and susceptible Chilean biotypes of Lolium multiflorum. Weed Biol. Manag. 4:56-8.

Pardo G, Cirujeda A, Aibar J, Cavero J, Zaragoza C, 2008. Weed harrowing in winter cereals under semi-arid conditions. Span. J. Agr. Res. 6:661-70.

Peigné J, Ball BC, Roger-Estrade J, David C, 2007. Is conservation tillage suitable for organic farming? Soil Use Manag. 23:129-44.

Pinke G, Karacsony P, Czucz B, Botta-Dukat Z, Lengyel A, 2012. The influence of environment, management and site context on species composition of summer arable weed vegetation in Hungary. Appl. Veg. Sci. 15:136-44.

Rasmussen IA, Askegaard M, Olesen JE, Kristensen K, 2006. Effects on weeds of management in newly converted organic crop rotations in Denmark. Agr. Ecosyst. Environ. 113:184-95.

Reddy KN, Koger CH, 2005. Herbicide-resistant crops and weed management. In Handbook of Sustainable Weed Management, Singh HP, Batish DR, and Kohli RK eds. The Haworth Press, Inc. Binghamton, NY. 966 pp.

Restuccia A, Lombardo S, Mauromicale G, 2019. Impact of a cultivation system upon the weed seedbank size and composition in a mediterranean environment. Agriculture. 9:192.

Riemens MM, van der Weide RY, Bleeker PO, Lotz LAP, 2007. Effect of stale seedbed preparations and subsequent weed control in lettuce (cv. Iceboll) on weed densities. Weed Res.
47:149-56.

Santín-Montanyá MI, Martín-Lammerding D, Zambranab E, Tenorio JL, 2016. Management of weed emergence and weed seed bank in response to different tillage, cropping systems and selected soil properties. Soil Till. Res. 161:38-46.

Swanton CJ, Shrestha A, Knezevic SZ, Roy RC, Ball-Coelho BR, 2000. Influence of tillage type on vertical weed seedbank distribution in a sandy soil. Can. J. Plant Sci. 80:455-57.

Tørresen KS, Skuterud R, 2002. Plant protection in spring cereal production with reduced tillage. IV. Changes in the weed flora and weed seedbank. Crop Prot. 21:179-93.

Van Gessel MJ, 2001. Glyphosate-resistant horseweed from Delaware. Weed Sci. 49:703-5.

Vanasse A, Leroux GD, 2000. Floristic diversity, size, and vertical distribution of the weed seedbank in ridge and conventional tillage systems. Weed Sci. 48:454-60.

Woźniak A, 2007. Content of weed seed in rendzina soil under spring triticale. Ann. Univ. Mariae Curie-Skłodowska, Sect. E, Agric. 62:250-6. (In Polish, abstract in English).

Woźniak A, Soroka M, 2015. Structure of weed communities occurring in crop rotation and monoculture of cereals. Int. J. Plant Prod. 9: 487-506.

Woźniak A, Soroka M, 2017. Effect of tillage systems on weed infestation of durum wheat. Int. J. Plant Prod. 11:453-60.

Woźniak A, Soroka M, 2018. Effect of crop rotation and tillage system on the weed infestation and yield of spring wheat and on soil properties. Appl. Ecol. Environ. Res. 16:3087-96.

Woźniak A, 2018. Effect of tillage system on the structure of weed infestation of winter wheat. Span. J. Agric. Res. 16:e1009.

Woźniak A, Rachoń L, 2019. Effect of tillage systems on pea crop infestation with weeds. Arch. Agron. Soil Sci. 65:877-85.

Yenish JP, Doll JD, Buhler DD, 1992. Effects of tillage on vertical distribution and viability of weeds in soil. Weed Sci. 40:429-33.

Young B, Gibson D, Gage K, Matthews J, Jordan D, Owen M, Shaw D, Weller S, Wilson R, 2013. Agricultural weeds in glyphosate-resistant cropping systems in the United States. Weed Sci. 61:85-97.

Yuan CI, Mou-Yen C, Yih-Ming C, 2002. Triple mechanisms of glyphosate-resistance in a naturally occurring glyphosateresistant plant Dicliptera chinensis. Plant Sci. 163:543-54. 